\title{
Mashups mix data into global service
}

Will 2006 be the year of the mashup? Originally used to describe the mixing together of musical tracks, the term now refers to websites that weave data from different sources into a new service. They are becoming increasingly popular, especially for plotting data on maps, covering anything from cafés offering wireless Internet access to traffic conditions. And advocates say they could fundamentally change many areas of science - if researchers can be persuaded to share their data.

Some disciplines already have software that allows data from different sources to be combined seamlessly. For example, abioinformatician can get a gene sequence from the GenBank database, its homologues using the BLAST alignment service, and the resulting protein structures from the Swiss-Model site in one step. And an astronomer can automatically collate all available data for an object, taken by different telescopes at various wavelengths, into one place, rather than having to check each source individually.

So far, only researchers with advanced programming skills, working in fields organized enough to have data online and tagged appropriately, have been able to do this. But simpler computer languages and tools are helping.

Google's maps database, for example, allows users to integrate data into it using just ten lines of code (www.google.com/apis/ maps). UniProt, the world's largest protein database, is developing its existing public interfaces to protein sequence data to encourage outside users to access and reuse its data.

The biodiversity community is one group working to develop such services. To demonstrate the principle, Roderic Page of the University of Glasgow, UK, built what he describes as a "toy" - a mashup called Ispecies.org (hittp:// darwin.zoology.gla.ac.uk/ rpage/ispecies). If you type in a species name it builds a web page for it showing sequence data from GenBank, literature from Google Scholar and photos from a Yahoo image search. If you could pool data from every museum or lab in the world, "you could do amazing things", says Page.

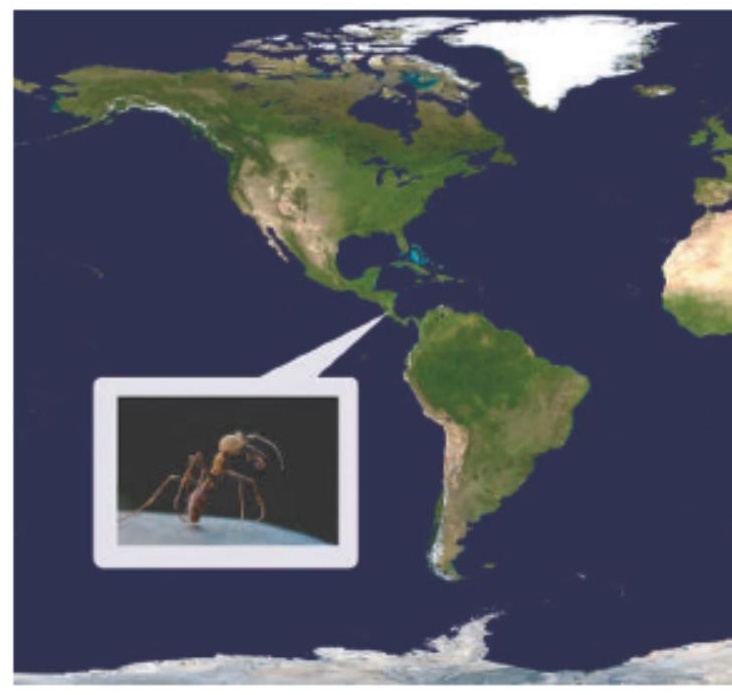

Web crawling antresearchers are bringing together information from a variety of sources.

Donat Agosti of the Natural History Museum in Bern, Switzerland, is working on this. $\mathrm{He}$ is one of the driving forces behind AntBase and AntWeb, which bring together data on some 12,000 ant species. He hopes 쫄 that, as well as searching, people will reuse the 8 data to create phylogenetic trees or models of geographic distribution.

This would provide the means for a realtime, worldwide collaboration of systematicists, says Norman Johnson, an entomologist

\section{Intelligent design verdict set to sway other cases}

\section{WASHINGTON DC}

A high-profile trial centred on the teaching of evolution is over. High-school students in Dover, Pennsylvania, will not now hear an announcement promoting intelligent design - the idea that an intelligent creator shaped today's organisms - before taking lessons on evolution. On 20 December, federal judge John Jones struck down a local school-board decision in a scathing 139-page rebuke to the intelligent-design movement. But other challenges to evolution are simmering across the country - and the Dover decision could influence their outcome, some say.

Such fights usually originate at the state level — in the form of legislation or the setting of state-wide education standards or at the school-district level, where local standards and curricula are generally set.

A recent study from the Washington-based Thomas B. Fordham Instituteinto science curriculum standards gave failing grades to 15 states (see map). Alabama students, for instance, learn from biology textbooks adorned with a sticker describing evolution as "controversial". But in Ohio, which passed, some students are taught from a stateapproved lesson plan called "critical analysis of evolution",in which they research and present pro- and anti-evolution viewpoints.

Robin Hovis, a member of the Ohio state board of education, says the Dover case may affect the future of the lesson plan. "It certainly gave those of us on the board who objected renewed hope," he adds. In Cobb County, Georgia, an appeals court is set to rule on a lower-court judgement deeming similar stickers unconstitutional.

And in Kansas, a school-board primary election next August could reshape the state's educational landscape. Board members who edited the education standards to include "scientific criticisms" of evolution face challenges by moderate Republicans who want such language weeded out (see Nature 438, 267; 2005).
In another twist, a group of Christian schools is suing the University of California for refusing to recognize certain high-school courses, including biology classes that use textbooks taking an anti-evolution view. The university has filed for dismissal, and expects to hear from the judge in a few months. "The Dover verdict says schools can't teach these non-scientificideas as science, so that supports us," says Christopher Patti, a lawyer with the university.

Legislation promoting intelligent design or similar anti-evolution ideas was introduced in more than a dozen states in 2005. Most died a hastydeath, according to Nick Matzke, spokesman for the National Center for Science Education, a Californiabased non-profit organization that fights for evolution education. He and others hope that the Dover decision will help quash the promotion of intelligent design, which they say is a legal strategy for introducing religion into the classroom. "Court decisions 
